$$
\text { タービン用高 } \mathrm{Cr} \text { 鋼の時効およびクリープに伴う }
$$

スモールパンチ試験特性の変化

渡部 康明* 山下 満男** 和泉 栄**

駒崎 慎一 $* * *$ 森 幸貴 $* * * *$

\title{
Changes in Small Punch Test Characteristic of High Chromium Steel for Steam Turbine due to Aging and Creep
}

by

\author{
Yasuaki Watanabe*, Mitsuo Yamashita**, Sakae Izumi**, \\ Shin-ichi KomAZAKI*** and Koki Mori ${ }^{* * *}$
}

\begin{abstract}
A European 10Cr cast steel, GX12CrMoWVNbN10-1-1, which has been recently used in the steam turbine components of USC power plant, was subjected to thermal aging at 610,630 , and $650^{\circ} \mathrm{C}$ and creep test. The small punch (SP) test was carried out at the temperature range from -196 to $80^{\circ} \mathrm{C}$ using those aged and creep damaged steels to examine an applicability of the SP testing technique to the assessment of aging degradation. The experimental results revealed that the maximum load and the displacement to fracture changed depending on the aging and creep conditions, respectively. The temperature corresponding to the SP fracture energy of $1 \mathrm{~J}, \mathrm{~T}_{1 \mathrm{~J}}$, was employed for investigating the change in ductile-brittle transition property for convenience. The $\mathrm{T}_{1 \mathrm{~J}}$, which changed to the higher temperature side due to aging and creep at the beginning, decreased gradually with increasing Larson-Miller parameter (LMP), resulting in the recovery of embrittlement. Laves phase was clearly observed at the initiation site of quasi-cleavage cracking and the inside of dimple on the fracture surfaces. The $\mathrm{T}_{1 \mathrm{~J}}$ was well correlated with the number density of Laves phase, and it increased with increasing density. These results indicated that the precipitation and coarsening of Laves phase was closely associated with the change in SP ductile-brittle transition behavior. Additionally, it was also found that the tensile strength predicted based on the SP test result was relatively in good agreement with the measured one, and it had a tendency to decrease with increasing LMP.
\end{abstract}

Key words:

High chromium steel, Ductile-brittle transition property, Thermal aging, Creep, Laves phase, Small punch test

\section{1 緒言}

火力発電プラントでは発電効率の向上に向け，蒸気温 度, 圧力の高温高圧化が進められており, タービンに用い られる部材は低合金鋼から高 $\mathrm{Cr}$ 鋼へと変遷している．現 在主流である超々臨界圧発電プラントの主要タービン部 品には 9〜 $12 \%$ の $\mathrm{Cr}$ を含有する高 $\mathrm{Cr}$ 鋼が使用されてお り, 高 $\mathrm{Cr}$ 鋼は $\mathrm{Mo}, \mathrm{W}$ 等を添加寸ることで高いクリープ強 度特性を有している。 しかし, 高 $\mathrm{Cr}$ 鋼は高温環境下にて 長時間使用されると Laves 相の析出, 粗大化に伴うじん性 の低下, 固溶強化元素の析出、組織回復に伴う強度低下な ど機械的特性の劣化が生じることが知られている ${ }^{1)}{ }^{2)}$. そ のため, 長時間使用される高 $\mathrm{Cr}$ 鋼の機械的特性を把握す ることはタービンの信頼性を確保する上で重要である.
機械的特性評価には引張試験やシャルピー試験などが用 いられるが，試験片サイズが大きい場合は実機損傷も大 きくなるため, サンプル採取が困難である. そこで, 微小 試験法のひとつであるスモールパンチ (以下, SP) 試験法

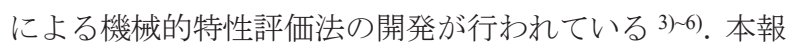
では超々臨界圧発電のタービン部材に使用される高 $\mathrm{Cr}$ 鋼 について, 加熱時効およびクリープ損傷材を作製し, SP 試 験にて破壊特性の変化を調査し, 得られた結果から劣化 に伴う延性-ぜい性遷移特性, 引張特性の変化を評価した。

\section{2 供試材料および実験方法}

\section{$2 \cdot 1$ 供試材料}

供試材料の化学組成を Table 1 に示す. 供試材料は, 夕 ービン用改良 $12 \% \mathrm{Cr}$ 鋳鋼である欧州系材料の

$\dagger$ 原稿受理 令和 2 年 7 月 10 日 Received July10,2020

(C)2021 The Society of Materials Science, Japan

* 富士電機(株) 技術開発本部 $\bar{\top} 191-8502$ 日野市富士町

Corporate R\&D Headquarters, Fuji Electric Co., Ltd., Fuji-machi, Hino 191-8502.

** 富士電機(株) 川崎工場 発電プラント事業本部 テ210-9530 川崎市川崎区田辺新田

Kawasaki Factory, Power \& New Energy Business Group, Fuji Electric Co., Ltd., Tanabeshinden, Kawasaki-ku, Kawasaki 210-9530.

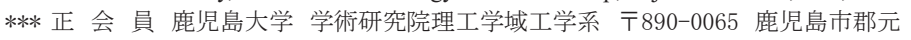

Research Field in Engineering, Science and Engineering Area, Research and Education Assembly, Kagoshima University, Korimoto, Kagoshima 890-0065.

****鹿児島大学 工学部 機械工学科 $\bar{\top} 890-0065$ 鹿児島市郡元

Department of Mechanical Engineering, Faculty of Engineering, Kagoshima University, Korimoto, Kagoshima 890-0065. 
GX12CrMoWVNbN10-1-1 を用いた. 加熱時効に伴う SP 試 験特性を調査するため，1095 1105 ${ }^{\circ} \mathrm{C}$ て焼ならし， $730 \sim 735^{\circ} \mathrm{C}$ に焼戻し処理を施した後, $610,630,650^{\circ} \mathrm{C} の$ 各温度にて 10000，20000h の時効材を作製した。また，応 力負荷の影響を調べるため $610^{\circ} \mathrm{C} / 90 \mathrm{MPa} ， 630^{\circ} \mathrm{C} / 70 \mathrm{MPa}$, $650^{\circ} \mathrm{C} / 50 \mathrm{MPa}$ の条件下で $10000 \mathrm{hr}$ のクリープ試験を実施 し，クリープ損傷材を作製した。

$2 \cdot 2$ 実験方法

SP 試験治具の概略図を Fig. 1 に示す. SP 試験片として $\phi 8.0 \times \mathrm{t} 0.5 \pm 0.005 \mathrm{~mm}$ の微小ディスク試験片を採取し, 試 験片表面の最終仕上げ加工は $0.03 \mu \mathrm{m}$ アルミナ砥粒にて鏡 面仕上げとした. 試験片を上下部ダイ間にセットし, ボル トにてダイを締付固定した後， $\phi 2.38 \mathrm{~mm}$ の鋼球を試験片 上面にセットし，所定の試験温度に 10 分間保持した。 そ の後, 電動アクチュエータにより変位速度 $0.2 \mathrm{~mm} / \mathrm{min}$ に て試験片に荷重を負荷した. 試験温度範囲は-196〜 80 $\mathrm{C}$ で あり，-196 ${ }^{\circ} \mathrm{C}$ は液体窒素， $-150^{\circ} \mathrm{C},-100^{\circ} \mathrm{C},-50^{\circ} \mathrm{C}, 0^{\circ} \mathrm{C}$ は液 体窒素とイソペンタンの混合液を用い, $50^{\circ} \mathrm{C}, 80^{\circ} \mathrm{C}$ は温水 を用いて試験温度を調整した。パンチャーに取り付けた ロードセルおよび変位計から荷重-変位曲線を求め，荷重 が最大荷重から $20 \%$ 低下した点を破壞と定義し，破壊に 至るまでの変位と荷重の面積から SP 破壊エネルギーを算 出した.

Table 1 Chemical composition (wt $\%$ ).

\begin{tabular}{ccccccc}
\hline $\mathrm{C}$ & $\mathrm{Si}$ & $\mathrm{Mn}$ & $\mathrm{P}$ & $\mathrm{S}$ & $\mathrm{Cr}$ & $\mathrm{Mo}$ \\
\hline 0.13 & 0.20 & 0.87 & 0.019 & 0.009 & 9.89 & 0.94 \\
\hline $\mathrm{Ni}$ & $\mathrm{Al}$ & $\mathrm{V}$ & $\mathrm{W}$ & $\mathrm{Nb}$ & $\mathrm{N}$ & \\
\hline 0.71 & 0.001 & 0.23 & 1.049 & 0.05 & 0.042 & \\
\hline
\end{tabular}

Fig. 1 Schematic view of specimen holder.

\section{3 実験結果および考察}

$3 \cdot 1$ 時効およびクリープに伴う硬さ, 組織の変化

Fig. 2 にSEM 反射電子像にて撮影した，焼戻しまま材 および $650^{\circ} \mathrm{C} / 20000 \mathrm{~h}$ 時効材の粒界三重点における組織写 真を示す。本鋼種は焼戻しマルテンサイト組織を呈して いる. 焼戻しまま材は粒界, 粒内に微細な炭化物の析出が 認められた。一方，時効材は新たに Laves 相（図中の白い $1 \mu \mathrm{m}$ 程度の析出物）が粒界，粒内に析出していた。
時効およびクリープに伴う硬さ変化について LarsonMiller パラメータ（LMP）にて整理した結果を Fig. 3 に示 す.ここで, 本鋼種の材料特性および析出状態は時効温度 および時間により変化するため, 温度, 時間の効果を統一 的に表現できる LMP を用いた。 時効材は LMP の増加に 伴い軟化傾向を示し, 高温度, 長時間側では硬さ変化が軽 微である.また，クリープ損傷材は時効材に比べ, 硬さは 著しく低下しており, 応力負荷による軟化の促進が認め られる。

時効およびクリープに伴う Laves 相の析出状態の変化 として, Laves 相の平均粒面積と個数密度を LMP にて整 理した結果をそれぞれ Fig. 4, 5 に示す. なお，平均粒面 積はSEM 反射電子像にて旧オーステナイト粒界の三重点 を 5000 倍にて 3〜5 視野撮影し，視野中の Laves 相につ いて画像処理を用いて定量化した全析出面積を析出個数 で除した平均值である. 個数密度は同観察視野中の Laves 相の析出個数を定量化し, 視野面積にて除した平均值で ある. 時効材の Laves 相の平均粒面積は LMP の増加に伴 い単調に増加しており, 時効に伴う Laves 相の粗大化が認 められる. クリープ損傷材の Laves 相の平均粒面積は時効 材に比べ, 高温, 長時間側にて増加しており, 応力負荷に よる Laves 相の粗大化促進が認められる。一方， Laves 相 の個数密度は LMP の増加に伴い減少する傾向が認められ， 時効材に比べクリープ損傷材のほうが高温長時間側にて 僅かに小さいが，ばらつきも考慮すると明瞭な差異とは いえない.
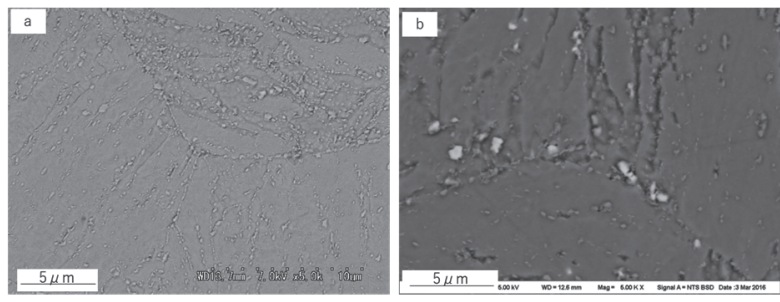

Fig. 2 SEM micrographs of (a) as-tempered and (b) $650^{\circ} \mathrm{C} / 20000 \mathrm{~h}$ aged.

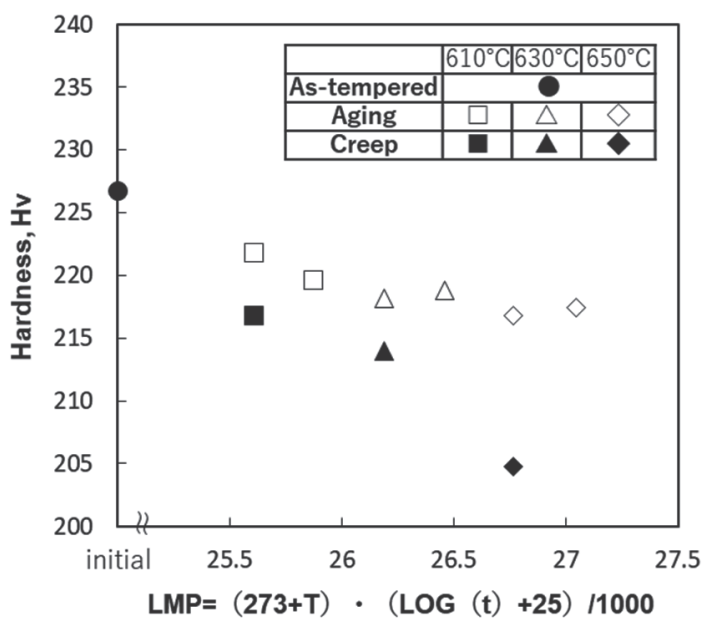

Fig. 3 Changes in Vickers hardness with aging and creep. 


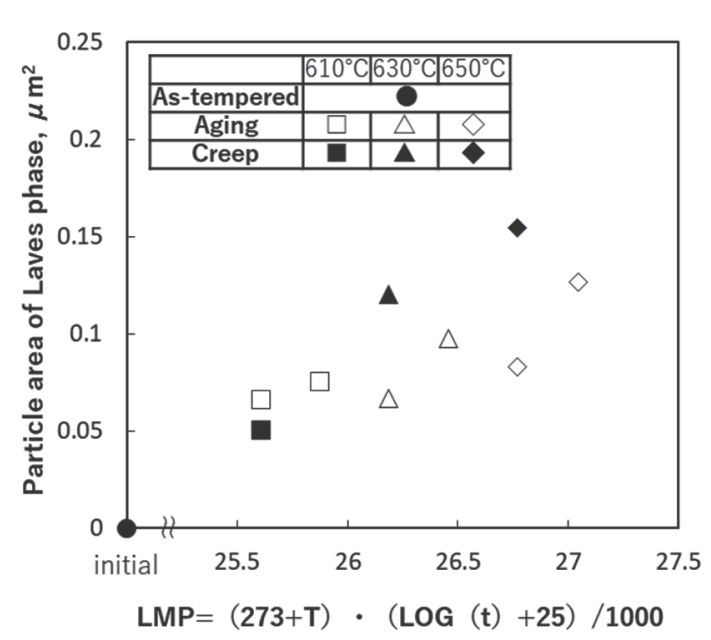

Fig. 4 Changes in particle area of Laves phase with aging and creep.

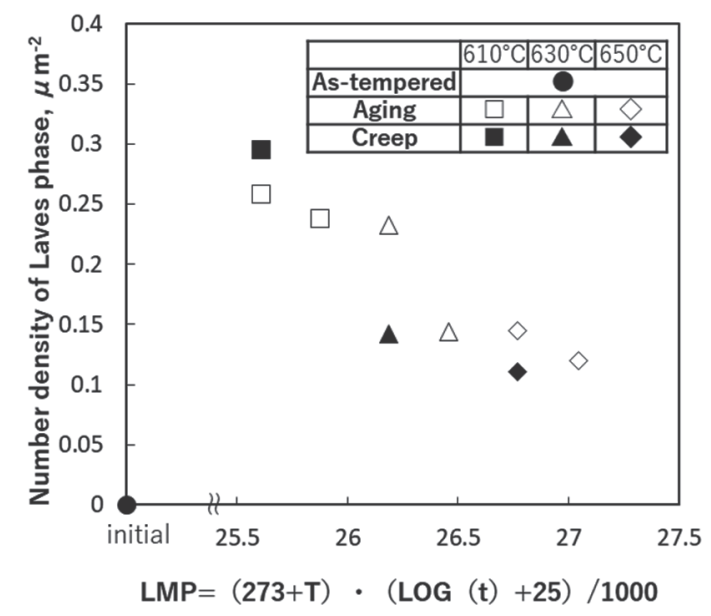

Fig. 5 Changes in number density of Laves phase with aging and creep.

\section{$3 \cdot 2$ 時効およびクリープに伴う SP 試験特性の変化}

SP 試験結果に及ぼす試験温度の影響の一例として, $630^{\circ} \mathrm{C} / 20000 \mathrm{~h}$ 時効材の荷重-変位曲線を Fig. 6 に示す. $-196^{\circ} \mathrm{C}$ から $-50^{\circ} \mathrm{C}$ 範囲では試験温度の増加に伴い最大荷 重は高くなり，破断時の変位は増大している。 $-50^{\circ} \mathrm{C}$ に比 べ $20^{\circ} \mathrm{C}, 80^{\circ} \mathrm{C}$ では最大荷重および破断変位は低下してい る. $-150^{\circ} \mathrm{C},-50^{\circ} \mathrm{C}, 20^{\circ} \mathrm{C}$ 試験後の SP 試験片外観を Fig. 7 に示す。 $-150^{\circ} \mathrm{C}$ では試験片中央付近で放射線状に破壊が

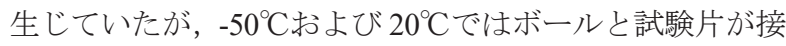
触する円周上に沿って破壊が生じている．微視的な破面 様相は後述するが, $-50^{\circ} \mathrm{C}$ 以下は延性, ぜい性の混合破面 を呈していることから，延性-ぜい性遷移域と考えられる $-50^{\circ} \mathrm{C}$ 以上ではディンプルを伴う粒内延性破面を呈してい ることから上部棚と考えられる.

荷重-変位曲線に及ぼす時効時間とクリープの影響の一 例として, 室温における荷重-変位曲線の変化を Fig. 8 に 示す. 時効温度 $610^{\circ} \mathrm{C}, 630^{\circ} \mathrm{C}$ では時効時間の増加に伴う 最大荷重の低下および破断変位の減少がみられる. $650^{\circ} \mathrm{C}$ では時効時間の増加に伴い最大荷重および破断変位は増
加している. クリープ損傷材は, 同時効時間である $10000 \mathrm{~h}$ 時効材に比べ, $610^{\circ} \mathrm{C} / 90 \mathrm{MPa}$ は最大荷重がわずかに低下し ているが，破断延性はわずかに増加している。 $630^{\circ} \mathrm{C}$ $170 \mathrm{MPa}$ および $650^{\circ} \mathrm{C} / 50 \mathrm{MPa}$ では応力負荷により最大荷重, 破断延性ともに低下がみられる。

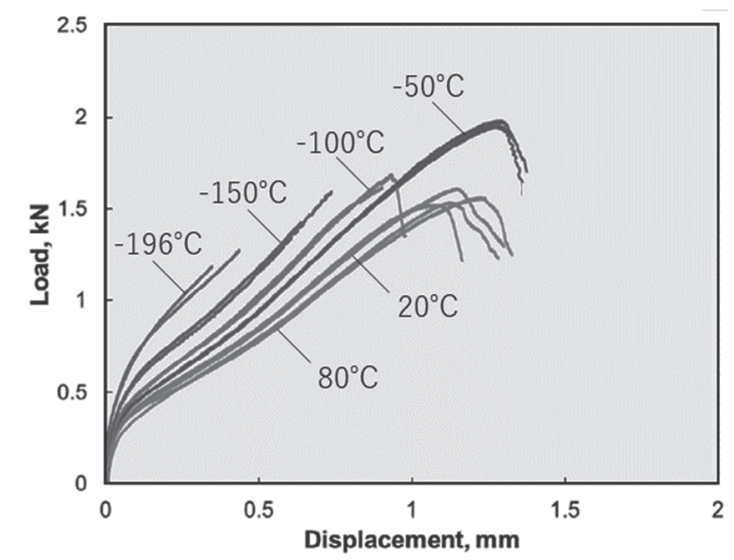

Fig. 6 Load-displacement curves at various temperatures.

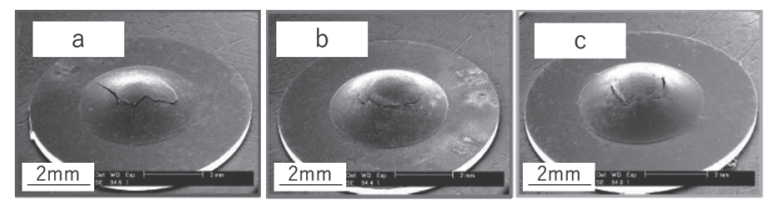

Fig. 7 Exterior photos of specimens tested at (a) $-150^{\circ} \mathrm{C}$, (b) $-50^{\circ} \mathrm{C}$ and (c) $20^{\circ} \mathrm{C}$.
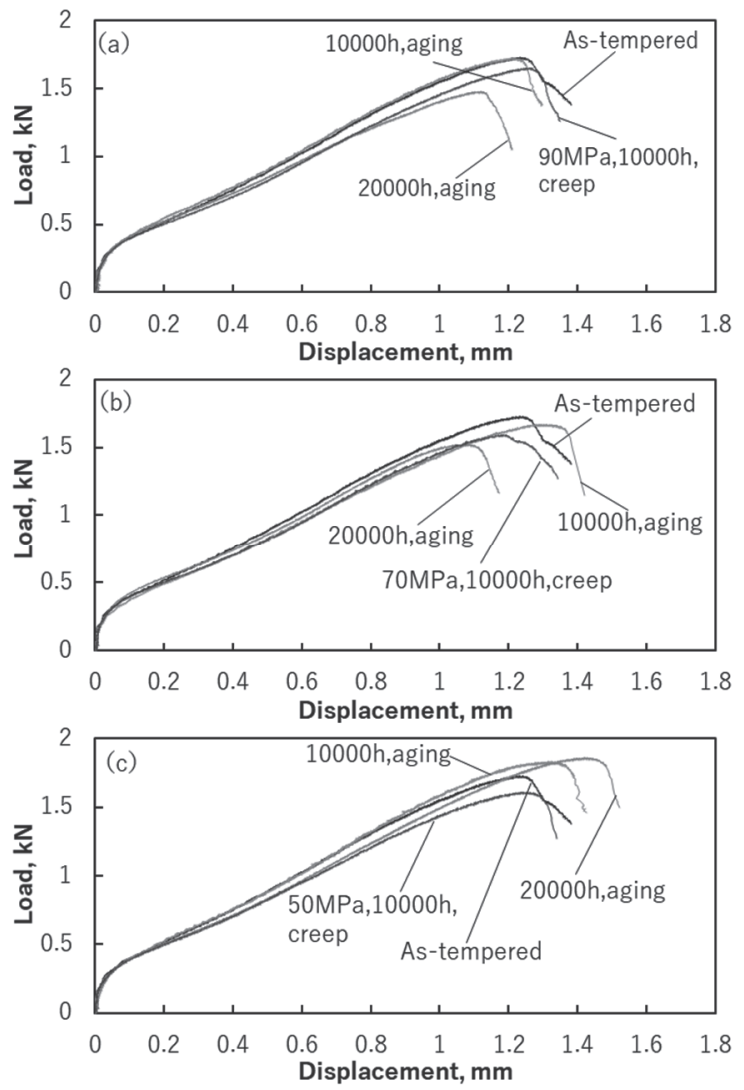

Fig. 8 Changes in load-displacement curve with aging and creep at (a) $610^{\circ} \mathrm{C}$, (b) $630^{\circ} \mathrm{C}$ and (c) $650^{\circ} \mathrm{C}$. 
$3 \cdot 3$ 時効およびクリープに伴う SP 遷移特性の変化

SP 試験における延性-ぜい性遷移特性に及ぼす時効時 間とクリープの影響の一例として， $610^{\circ} \mathrm{C}$ 時効材およびク リープ損傷材の SP 延性-ぜい性遷移曲線を Fig. 9 に示す. $-196^{\circ} \mathrm{C}$ から $-50^{\circ} \mathrm{C}$ 温度域では, 試験温度の増加に伴い SP 破壊エネルギーは増加していることから，遷移域と考え られる。遷移域において, $610^{\circ} \mathrm{C}$ 時効材およびクリープ損 傷材の SP 破壊エネルギーは焼戻しまま材に比べ低下して おり，時効およびクリープに伴うぜい化傾向を示してい る.焼戻しまま材の $\mathrm{SP}$ 破壊エネルギーが最大となる $-50^{\circ} \mathrm{C}$ 以上の温度域では, 試験温度の増加に伴い SP 破壊エネル ギーは低下傾向を示している，後述する破面観察の結果 と合わせ， $-50^{\circ} \mathrm{C}$ 以上の温度域は上部棚と考えられる。上 部棚についても焼戻しまま材に比べ，時効材およびクリ 一プ損傷材ともにばらつきはあるものの，全体的に SP 破 壊エネルギーは低下している。この結果から，遷移域およ び上部棚ともに時効およびクリープに伴うぜい化傾向を 示している. なお, 時効時間の増加あるいは応力負荷によ る遷移域の SP 破壊エネルギーの变化に顕著な差異はみら れなかった。

他の劣化条件を含めた SP 試験における延性-ぜい性遷 移特性を Table 2 に示す。ここで, SP 遷移温度の SPDBTT

（ $\mathrm{T}_{\mathrm{Em} / 2}$ ) は延性-ぜい性遷移曲線における最大 SP 破壊エ ネルギーEm の $1 / 2$ の值に相当する温度であり, 従来報告 されている SPDBTT と同様の定義である ${ }^{7)} . \operatorname{SPDBTT}\left(\mathrm{T}_{1 \mathrm{~J}}\right)$ は SP 破壊エネルギーEsp=1（J）に相当する温度である。 $610^{\circ} \mathrm{C}$ おび $650^{\circ} \mathrm{C}$ 時効材では， $10000 \mathrm{~h}$ 時効材に比べ 20000h 時効材の SPDBTT（TEm/2）は低温側へと移行して おり, 延性の回復傾向を示している.一方, $\operatorname{SPDBTT}\left(\mathrm{T}_{1 \mathrm{~J}}\right)$ は時効により全体的に高温側へと移行しており，ぜい化 傾向がみられる. 今回, 延性ぜい性遷移挙動がより明瞭に 表現されている SPDBTT（T1J）を延性-ぜい性遷移挙動の 指標として採用した。

$\mathrm{SP}$ 試験における延性-ぜい性遷移温度に及ぼす時効お よびクリープの影響として SPDBTT $\left(\mathrm{T}_{1 \mathrm{~J}}\right)$ をLMP にて整 理した結果を Fig. 10 に示す. 時効材およびクリープ損傷 材の SPDBTT $\left(\mathrm{T}_{1 \mathrm{~J}}\right)$ は焼戻しまま材に比べ, 高温側に位置 しており，時効およびクリープに伴うぜい化傾向がみら れる。しかし，LMPの増加に伴い SPDBTT（ $\mathrm{T}_{1 \mathrm{~J}}$ ） は全体 的に徐々に低温化しており，延性が回復していく傾向に ある.クリープ損傷材と同温度の時効材を比較すると, $610^{\circ} \mathrm{C}, 630^{\circ} \mathrm{C}$ リープ損傷材の $\operatorname{SPDBTT}\left(\mathrm{T}_{1 \mathrm{~J}}\right)$ はわずかに

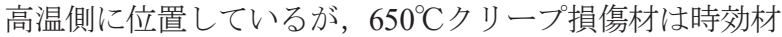
とほぼ同等の温度である，そのため，SP 試験における延 性-ぜい性遷移挙動に及ぼす応力負荷の影響については今 回の結果から明確なことは言えない.

このように，本鋼種の SP 試験における延性-ぜい性遷 移特性は時効およびクリープに伴いぜい化傾向を示すが, 高温長時間側では徐々に延性が回復するという結果が得 られた。

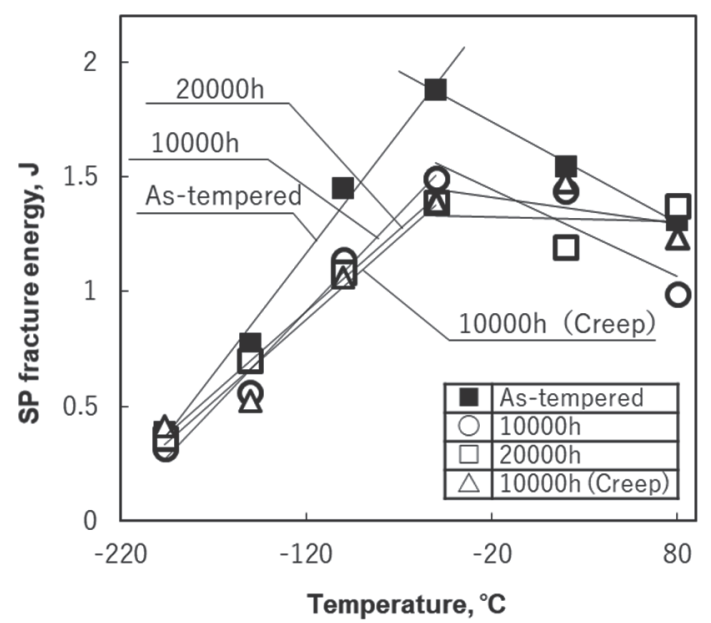

Fig. 9 Effects of thermal aging and creep on SP ductilebrittle transition curve.

Table 2 SP fracture properties.

\begin{tabular}{|c|c|c|c|c|c|}
\hline \multirow{2}{*}{$\begin{array}{c}\text { Temp. } \\
\left({ }^{\circ} \mathrm{C}\right)\end{array}$} & \multirow{2}{*}{$\begin{array}{l}\text { Stress } \\
(\mathrm{MPa})\end{array}$} & \multirow{2}{*}{$\begin{array}{c}\text { Time } \\
\text { (h) }\end{array}$} & \multirow{2}{*}{$\begin{array}{l}\mathrm{Em} \\
(\mathrm{J})\end{array}$} & \multicolumn{2}{|c|}{ SPDBTT $\left({ }^{\circ} \mathrm{C}\right)$} \\
\hline & & & & $\mathrm{T}_{\mathrm{Em} / 2}$ & $\mathrm{~T}_{1 \mathrm{~J}}$ \\
\hline- & - & - & 1.88 & -142 & -135 \\
\hline \multirow[t]{3}{*}{610} & - & 10000 & 1.49 & -132 & -109 \\
\hline & - & 20000 & 1.44 & -150 & -108 \\
\hline & 90 & 10000 & 1.40 & -139 & -103 \\
\hline \multirow[t]{3}{*}{630} & - & 10000 & 1.61 & -146 & -126 \\
\hline & - & 20000 & 1.65 & -134 & -112 \\
\hline & 70 & 10000 & 1.55 & -143 & -115 \\
\hline \multirow[t]{3}{*}{650} & - & 10000 & 1.73 & -140 & -131 \\
\hline & - & 20000 & 1.65 & -150 & -128 \\
\hline & 50 & 10000 & 1.65 & -157 & -130 \\
\hline
\end{tabular}

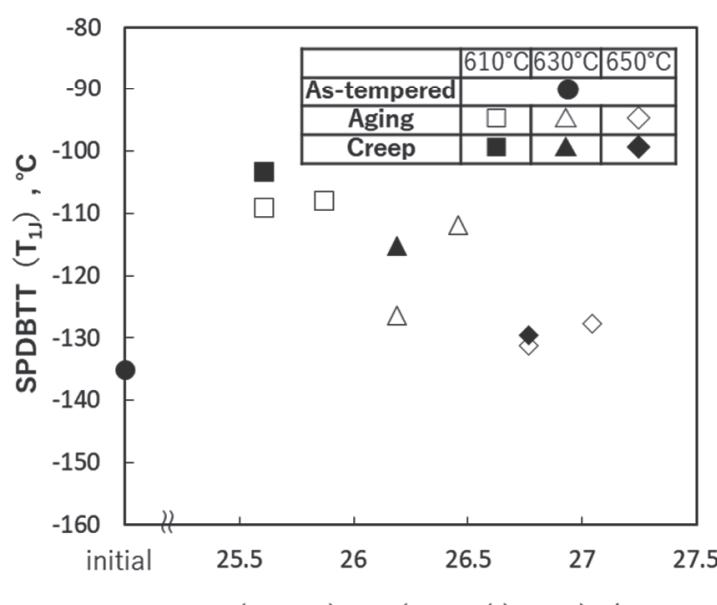

$\mathrm{LMP}=(273+\mathrm{T}) \cdot(\operatorname{LOG}(\mathbf{t})+25) / 1000$

Fig. 10 SPDBTT $\left(\mathrm{T}_{1 \mathrm{~J}}\right)$ plotted as a function of LMP.

\section{$3 \cdot 4$ SP 試験後の破壊状況}

焼戻しまま材と $650^{\circ} \mathrm{C} / 10000 \mathrm{~h}$ 時効材の上部棚 $\left(20^{\circ} \mathrm{C}\right)$, 遷移域 $\left(-100^{\circ} \mathrm{C},-196^{\circ} \mathrm{C}\right)$ における微視的な破面観察写真

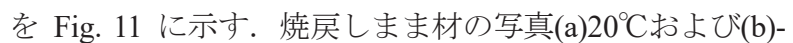
$100^{\circ} \mathrm{C}$ における破面形態はディンプルを伴う粒内延性破 面であり, ディンプル内に微細な析出物が認められた。 写 真(c)-196 ${ }^{\circ} \mathrm{C}$ では粒内擬へき開割れを呈しており, 擬へき開 割れの起点に明瞭な析出物等は認められなかった。一方, 時効材の写真 $(\mathrm{d}) 20^{\circ} \mathrm{C}$ における破面形態は焼戻しまま材と 
同様，ディンプルを伴う粒内延性破面を呈していたが，デ インプル内に微細な析出物の他, 粗大な Laves 相が認めら

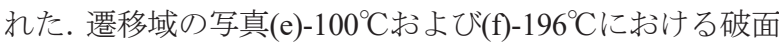
形態は典型的な粒内擬へき開割れを呈していた。一部粒 界割れが観察された時効材もあったが，焼戻しまま材と 異なり時効材の擬へき開割れ起点には Laves 相が観察さ れた。

SP 試験における延性-ぜい性遷移特性に及ぼす Laves 相 の析出状態の影響として, SPDBTT $\left(\mathrm{T}_{1 \mathrm{JJ}}\right)$ と Laves 相の個 数密度の関係を整理し Fig. 12 に示寸. 同図からわかるよ うに，多少ばらつきはあるものの，Laves 相の個数密度と SPDBTT（ $\mathrm{T}_{1 \mathrm{~J}}$ ）の間には比較的良好な相関が認められ， Laves 相の個数密度の増加に伴い SPDBTT $\left(\mathrm{T}_{1 \mathrm{~J}}\right)$ が高温化 している.

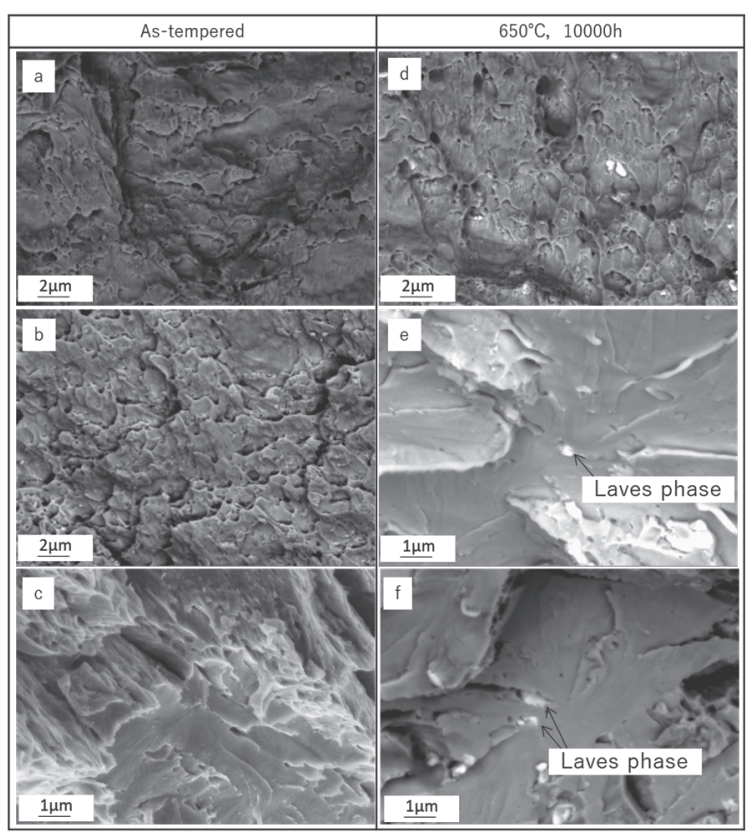

Fig. 11 Fracture surfaces of as-tempered and $650^{\circ} \mathrm{C} / 10000 \mathrm{~h}$ aged at test temperatures of $(\mathrm{a}, \mathrm{d}) 20^{\circ} \mathrm{C},(\mathrm{b}, \mathrm{e})-100^{\circ} \mathrm{C},(\mathrm{c}$, f) $-196^{\circ} \mathrm{C}$

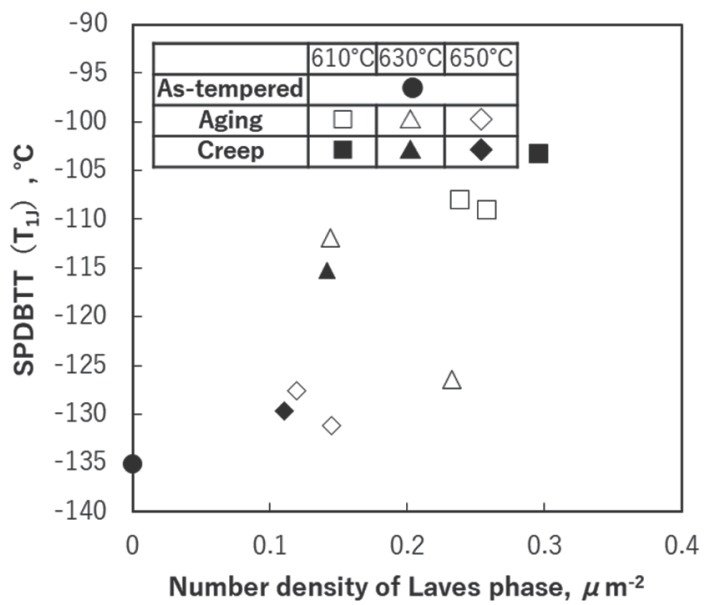

Fig. 12 SPDBTT $\left(\mathrm{T}_{1 \mathrm{~J}}\right)$ plotted as a function of number density of Laves phase.
$3 \cdot 5$ 時効に伴う引張特性の変化

Garcia ( $^{8)}$ は，SP 試験結果に基づき，式（1）および式 （2）を用いることで降伏強度および引張強度を予測でき ると報告している。

$$
\begin{aligned}
\sigma_{y} & =0.346 * \frac{F_{e}(0.05)}{h_{0}{ }^{2}} \\
\sigma_{B} & =0.277 * \frac{F_{m}}{u_{m} * h_{0}}
\end{aligned}
$$

ここで，Fe（0.05）は室温における SP 荷重-変位曲線に おける初期傾斜と並行な線を変位 $0.05 \mathrm{~mm}$ から引き, その 線と荷重-变位曲線との交点の荷重, $\mathrm{F}_{\mathrm{m}}$ は荷重-变位曲線に おける最大荷重, $\mathrm{u}_{\mathrm{m}}$ は最大荷重時の変位, $\mathrm{h}_{0}$ は初期板厚 である，焼戻しまま材で得られている室温における降伏 強度および引張強度と式 (1)，(2) を用いて算出したもの の関係を Garcia らの結果と合わせてそれぞれ Fig. 13, 14 に示寸. 本試験の結果も Garcia らの結果と比較的良く一 致しており，これは，式（1）および式（2）を用いること で SP 試験により本鋼種の引張特性を評価可能であること を示唆している. 式（2）を用いて時効材およびクリープ 損傷材の室温における引張強度を予測し，LMP にて整理 したものを Fig. 15 に示す. 時効材の引張強度は LMP の 増加に伴いわずかに低下している. また, クリープ損傷材 は時効材とほぼ同等であり, クリープの影響はほとんど 認められない.

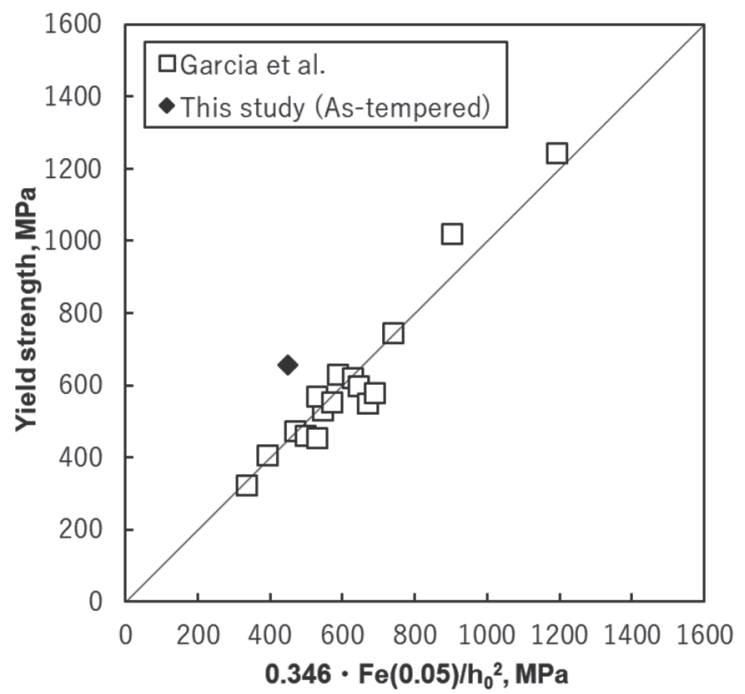

Fig. 13 Relationship between yield strength and $0.346 \mathrm{Fe}(0.05) / \mathrm{h}^{2}$. 


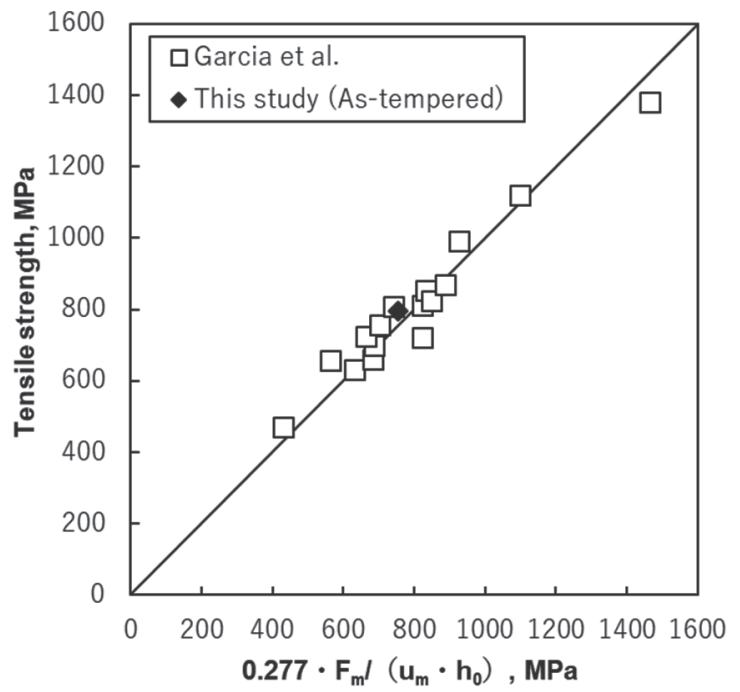

Fig. 14 Relationship between tensile strength and $0.277 \mathrm{~F}_{\mathrm{m}} /\left(\mathrm{u}_{\mathrm{m}} \cdot \mathrm{h}_{0}\right)$.

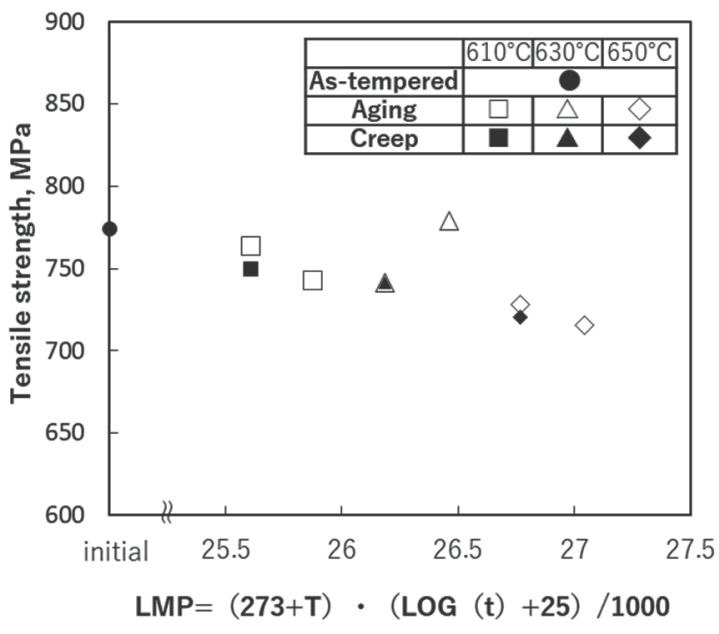

Fig. 15 Tensile strength plotted as a function of LMP.

$3 \cdot 6$ 考察

前節までに述べてきたとおり, 時効材の遷移域における ぜい性破面には Laves 相を起点とした擬へき開割れが観 察され, 上部棚域ではディンプル内で粗大な Laves 相を確 認することができた。また，遷移域においては，焼戻しま ま材に比べ時効材およびクリープ損傷材の SP 破壊エネル ギーが減少し, SP 延性-ぜい性遷移温度 ( $\mathrm{SPDBTT}\left(\mathrm{T}_{1 \mathrm{~J}}\right)$ ) も全体的に低温側へシフトした.さらには, $\operatorname{SPDBTT}\left(\mathrm{T}_{1 \mathrm{~J}}\right)$ と Laves 相個数密度との閒には良好な関係があり, 個数密 度の減少に伴い SPDBTT（ $\mathrm{T}_{1 \mathrm{~J}} ）$ が低温側へシフトし延性 が回復する傾向が認められた.

得られた結果は, 本鋼の加熱時効およびクリープに伴う ぜい化あるいは延性-ぜい性遷移特性の劣化が，Laves 相 の析出性状と密接に関係していることを示唆している. Laves 相の個数密度減少に伴う延性回復の理由としては, Laves 相起点の擬へき開割れの発生確率の低下が挙げら れるが, Laves 相の個数密度減少すなわち凝集・粗大化に よる析出強化能の低下に加え, マルテンサイトラス幅の
増加や転位密度の減少による軟化 (強度低下) も重要な役 割を果たしているものと思われ，その詳細な機構の解明 は今後の課題である.

\section{4 結 言}

タービン用改良 $12 \% \mathrm{Cr}$ 鋳鋼である $\mathrm{GX} 12 \mathrm{Cr}$ MoWVNbN10-1-1 の加熱時効およびクリープに伴う SP 破 壊特性の変化を調査し, 延性-ぜい性遷移特性, 引張特性 の変化を評価した結果，以下の知見を得た.

（1）加熱時効とクリープにより粒界・粒内に Laves 相が 析出し, その平均粒面積と個数密度は LMP の増加ととも にそれぞれ増加および減少した．また，硬さは加熱時効に 伴い単調に低下し, 応力負荷 (クリープ) による軟化の促 進効果が認められた.

（2）最大破壊エネルギーを含めた遷移域および上部棚に おける SP 破壊エネルギーは加熱時効とクリープによって 減少した。 SP 破壊エネルギーが $1 \mathrm{~J}$ となる温度を SP 延 性-ぜい性遷移温度と定義（SPDBTT $\left(\mathrm{T}_{1 \mathrm{~J}}\right)$ ) しその変化を調 べたところ，加熱時効とクリープによって高温側にシフ トした遷移温度が高温長時間側では徐々に低下し延性が 回復していくという結果が得られた.

（3）時効材の破面観察の結果，ディンプルの内部や擬へ き開割れの起点には Laves 相が観察された。また, $\operatorname{SPDBTT}\left(\mathrm{T}_{1 \mathrm{~J}}\right)$ と Laves 相の個数密度の間には良好な関係が 認めれ, 個数密度の増加とともに $\operatorname{SPDBTT}\left(\mathrm{T}_{1 J}\right)$ も単調に上 昇した。このようなことから, 上述した遷移温度の高温側 へのシフト (ぜい化) とその後の回復挙動には Laves 相の 析出・粗大化挙動が密接に関与しているものと考えられ た.

（4） SP 試験結果に基づいて予測した降伏強度や引張強度 は実測值と比較的良く一致した。時効材とクリープ損傷 材における引張強度を SP 試験結果に基づいて予測した結 果，LMP の増加とともに徐々に低下寸る傾向が認められ た.

\section{参 考 文 献}

1) S. Komazaki, S. Kishi, T. Shoji, H. Chiba and K. Suzuki, "Thermal aging embrittlement of $\mathrm{W}$ alloyed $9 \% \mathrm{Cr}$ ferritic steels and its evaluation by electrochemical Technique", Journal of the Society of Material Science, Japan, Vol.49, No.8, pp.919-926 (2000).

2) T. Onizawa, Y. Nagae and K. Kikuchi, "Effect of trace amount tungsten on long-term material properties of high Cr steels", Tetsu-to-Hagane, Vol.100, No.8, pp.9991005 (2014).

3) S. Komazaki, K. Mori, Y. Watanabe, M. Yamashita and S. Izumi, "Change in small punch test property of $12 \% \mathrm{Cr}$ ferritic steels used for turbine due to thermal aging and creep”, JSME, M\&M2017, OS1215.

4) T. Misawa, T. Adachi, M. Saito and Y. Hamaguchi, "Small punch tests for evaluating ductile-brittle transition behavior of irradiated ferritic steel", Journal of Nuclear Materials, Vol.150, pp.194-202 (1987). 
5) X. Jia and Y. Dai, "Small punch tests on martensitic/ferritic steels F82H, T91 and Optimax-A irradiated in SINQ Target-3", Journal of Nuclear Materials, Vol.323, pp.360-367 (2003).

6) T. Matsushita, M. L. Saucedo, M. Yotsutsuji, T. Shoji and H. Takahashi, "Correlation between a charpy $\mathrm{v}^{-}$ notch impact test and a small punch test in ductilebrittle fracture mode transition behavior", Transactions of the japan Society of Mechanical Engineers Series A, Vol.55, No.515, pp.1619-1622 (1989).

7) T. Sugimoto, K. Doki, S. Komazaki and T. Misawa, "Evaluation of toughness and creep properties of aged main value $\mathrm{CrMoV}$ casting steel by using small punch specimens", Tetsu-to-Hagane Vol.91, No.4 pp.408-414 (2005).

8) T. E. Garcia, C. Rodriguez, F. J. Belzunce and C. Suarez, "Estimation of the mechanical properties of metallic materials by means of the small punch test", Journal of Alloys and Compounds, Vol.582, pp.708-717 (2014). 